repaired or not, does not preclude patients from holding an ordinary driving licence." Possibly this statement should be extended to include suggestions relating to screening of patients of the relevant age group and sex to identify such high risk disease.

\section{Conclusions}

In this study there was no evidence to suggest that sudden natural death in road users, mainly from cardiovascular disease, represents a substantial threat to other road users. It is reasonable to presume that the number of road users will continue to increase, including the number of elderly road users in all categories. As yet there is no evidence of any appreciable drop in the $50 \%$ mortality from coronary heart disease, and there certainly appears to be no justification for restricting or depriving that group of patients of driving licences because of their pre-existing cardiac condition. The group represented by the men who collapsed and died suddenly on the road from ruptured undiagnosed abdominal aortic aneurysms should be a cause for concern. It would be economically unacceptable and inappropriate to institute routine medical examinations for all drivers over a certain age to rule out the possibility of cardiac conditions that are still responsible for the vast majority of natural deaths on the road. In relation to these conditions the recommendations in the handbook dealing with medical fitness to drive ${ }^{2}$ appear to be valid, appropriate, and sensible.

1 World Health Organisation. Accident prevention. 2nd rev. Geneva: WHO, 1956.

2 Medical Commission on Accident Prevention. Medical aspects of fitness to drive. A guide for medical practitioners. London: MCAP, 1985.

3 Christian MS, Gosnold JK, Kersley PN. Confirmation of death. Br Med J 1980;281:717-8.

4 American Association for Automotive Medicine. The abbreviated injury scale. Chicago, Ill: AAAM, 1985 .

5 Waller JA. Chronic medical conditions and traffic safety. $N$ Engl $\mathcal{J}$ Med 1965;273:1413-20.

6 Ysander L. The safety of drivers with chronic diseases. $\mathrm{Br} \mathcal{F}$ Ind Med 1966;23:28-36.

7 Grattan E, Jeffcoate GO. Medical factors and road accidents. $\mathrm{Br}$ Med $\mathcal{J}$ $1968 ; \mathrm{i}: 75$.

8 Baker S, Spitz WU. An evaluation of the hazard created by a natural death at the wheel. N Engl f Med 1970;283:405-9.

9 Road Traffic Act 1974. London: HMSO, 1974.

10 Jenkins J, Sainsbury P. Single-car road deaths-disguised suicides? Br Med $\mathcal{f}$ 1980;281:1041.

11 Collins J. Screening for abdominal aortic aneurysms. Br $\mathcal{F}$ Surg 1985;72:851-2.

12 Gowlands-Hopkins MF. Abdominal aortic aneurysms. Br Med $\mathcal{F}$ 1987;294 $790-1$
Cobbold Laboratories, University College and Middlesex School of Medicine, London WIN 8AA

R Homburg, MB, research fellow

N A Armar, MRCOG, research fellow

A Eshel, MD, research fellow J Adams, DMU, senior ultrasonographer H S Jacobs, FRCP, professor of reproductive endocrinology

Correspondence to: Professor H Jacobs.

\title{
Influence of serum luteinising hormone concentrations on ovulation, conception, and early pregnancy loss in polycystic ovary syndrome
}

\author{
R Homburg, N A Armar, A Eshel, J Adams, H S Jacobs
}

\begin{abstract}
Women with the polycystic ovary syndrome do not respond well to treatment with luteinising hormone releasing hormone. To determine whether this might be due to an underlying endocrine disturbance basal concentrations of luteinising hormone were measured in 54 infertile women treated with pulsatile luteinising hormone releasing hormone and concentrations at the time of maximum follicular growth were measured in 23 of the patients. Forty one patients ovulated.
\end{abstract}

Forty one patients ovulated and 27 conceived, but nine pregnancies terminated within four weeks after ovulation. Basal luteinising hormone concentrations were significantly lower in those who conceived $(12.4$ (range 1-3-29.0) IU/l) than in those who did not (19.0 $(3.5-50.0) \mathrm{IU} / \mathrm{I})$ and in those whose pregnancy progressed $(9.6(1 \cdot 3-29.0)$ IU/1) than in those with early loss of pregnancy $(17.9(7 \cdot 0-29 \cdot 0)$ IU/1). Concentrations at the time of maximum follicular growth were significantly lower in women who ovulated $(9.4$ (2.9$35.4)$ IU/1) than in those who did not $(29.0(7 \cdot 0-50.0)$ IU/I) and in those who conceived (6.2 (2.9-8.5) IU/I) than in those who did not $(17.9(4 \cdot 0-50 \cdot 0)$ IU/I).

These results indicate that high concentrations of luteinising hormone during the follicular phase in women with polycystic ovaries have a deleterious effect on rates of conception and may be a causal factor in early pregnancy loss.

\section{Introduction}

Infertile women with polycystic ovaries who do not ovulate and are resistant to clomiphene do not respond well to treatment with luteinising hormone releasing hormone in terms of rates of ovulation and conception; moreover, these patients often suffer early loss of pregnancy. ${ }^{\prime}$ This disappointing outcome is in direct contrast to the excellent results obtained with the same treatment in patients with hypogonadotrophic hypogonadism.

Patients with the polycystic ovary syndrome often have raised basal concentrations of luteinising hormone ${ }^{2}$ and we have shown that, when ovulation is induced with pulsatile luteinising hormone releasing hormone, luteinising hormone concentrations often remain high throughout the follicular phase. ${ }^{3}$ In this study we measured luteinising hormone concentrations in patients with the polycystic ovary syndrome being treated with pulsatile luteinising hormone releasing hormone and related them to whether or not ovulation and conception occurred and to the fate of the pregnancy. We have reported the clinical results in 48 of the patients elsewhere. ${ }^{4}$

\section{Patients and methods}

In 54 patients who were infertile and had failed to ovulate in response to multiple courses of clomiphene citrate polycystic ovaries were detected by ultrasonography, using the criteria of Adams et al. ${ }^{\mathrm{s}}$ Eight of the women had amenorrhoea and 46 had oligomenorrhoea.

All patients were treated with pulsatile injections of $15 \mu \mathrm{g}$ luteinising hormone releasing hormone (Fertiral, Hoechst) given subcutaneously at intervals of 90 minutes with a miniaturised infusion pump. Twelve women failed to ovulate so were given luteinising hormone releasing hormone intravenously at the same dose and frequency. Ovulation was detected by ultrasonography and was confirmed by the appearance of a corpus luteum together with a serum progesterone concentration $\geqslant 25 \mathrm{nmol} / 1$ during the mid-luteal phase. Pregnancy was diagnosed when human chorionic gonadotrophin was detected in serum and a gestational sac was detected on ultrasonography. Early loss of 
pregnancy was defined as miscarriage within four weeks after ovulation.

Basal serum luteinising hormone concentrations were determined before treatment in all patients, and the results given here are the mean of two or more measurements. In addition, in the last 23 patients treated luteinising hormone concentrations were measured two or three times a week throughout treatment. The concentrations defined as occurring at the time of maximum follicular growth were those recorded five days before presumed ovulation. At this time the diameter of the largest follicle detected by ultrasonography was $10-15 \mathrm{~mm}$.

Serum luteinising hormone concentrations (World Health Organisation international reference preparation code number 68/40) and basal serum concentrations of testosterone, follicle stimulating hormone (78/549), and prolactin (WHO international standard code number $83 / 562$ ) were measured by radioimmunoassay. Body mass index (weight $(\mathbf{k g}) /(\text { height }(\mathbf{m}))^{2}$ ) was calculated for each patient. Statistical analyses were performed with the Mann-Whitney test.

\section{Results}

The 54 patients had 182 cycles of pulsatile luteinising hormone releasing hormone; this included 29 cycles of intravenous treatment in 12 patients. Ninety eight of the cycles were ovulatory: 41 patients ovulated and 27 conceived within eight months after the start of treatment. Early pregnancy loss occurred in nine women. There were 14 singleton and two twin deliveries at term and two mid-trimester abortions.

The patients were divided into those who did and did not ovulate and those who did and did not conceive, and the pregnancies were divided according

TABLE I-Mean (range) basal serum luteinising hormone concentrations in patients with polycystic ovaries treated with pulsatile luteinising hormone releasing hormone

\begin{tabular}{|c|c|c|c|c|}
\hline & & $\begin{array}{c}\text { No of } \\
\text { patients }\end{array}$ & $\begin{array}{l}\text { Basal luteinising } \\
\text { hormone (IU/l) }\end{array}$ & p Value \\
\hline Ovulation & $\left\{\begin{array}{l}\text { Yes } \\
\text { No }\end{array}\right.$ & $\begin{array}{l}41 \\
13\end{array}$ & $\left.\begin{array}{l}14 \cdot 0(1 \cdot 3-29 \cdot 7) \\
21 \cdot 1(2 \cdot 3-50 \cdot 0)\end{array}\right\}$ & $0 \cdot 2$ \\
\hline Conception & Yes & 27 & $12 \cdot 4(1 \cdot 3-29 \cdot 0)\}$ & 0.02 \\
\hline & No & $\begin{array}{r}27 \\
9\end{array}$ & $19 \cdot 0(3 \cdot 5-50 \cdot 0)\}$ & \\
\hline $\begin{array}{l}\text { Outcome of } \\
\text { pregnancy }\end{array}$ & $\left\{\begin{array}{l}\text { Early loss } \\
\text { Delivery* }\end{array}\right.$ & $\begin{array}{r}9 \\
18\end{array}$ & $\left.\begin{array}{r}17 \cdot 9(7 \cdot 0-29 \cdot 0) \\
9 \cdot 6(1 \cdot 3-29 \cdot 0)\end{array}\right\}$ & 0.01 \\
\hline
\end{tabular}

^Including two mid-trimester abortions.

TABLE II -Mean (range) serum luteinising hormone concentrations at time of maximum follicular growth in patients with polycystic ovaries treated with pulsatile luteinising hormone releasing hormone

\begin{tabular}{|c|c|c|c|c|}
\hline & & $\begin{array}{c}\text { No of } \\
\text { patients }\end{array}$ & $\begin{array}{l}\text { Basal luteinising } \\
\text { hormone (IU/l) }\end{array}$ & $\mathrm{p}$ Value \\
\hline Ovulation & $\left\{\begin{array}{l}\text { Yes } \\
\text { No }\end{array}\right.$ & $\begin{array}{r}19 \\
4\end{array}$ & $\left.\begin{array}{r}9 \cdot 4(2 \cdot 9-35 \cdot 4) \\
29 \cdot 0(7 \cdot 0-50 \cdot 0)\end{array}\right\}$ & 0.04 \\
\hline Conception & & $\begin{array}{l}10 \\
13\end{array}$ & $\begin{array}{r}6 \cdot 2(2 \cdot 9-8 \cdot 5) \\
17 \cdot 9(4 \cdot 0-50 \cdot 0)\end{array}$ & $<0.02$ \\
\hline $\begin{array}{l}\text { Outcome of } \\
\text { pregnancy }\end{array}$ & $\left\{\begin{array}{l}\text { Early loss } \\
\text { Delivery }\end{array}\right.$ & $\begin{array}{l}4 \\
6\end{array}$ & $\begin{array}{l}\mathbf{6} \cdot 8(5 \cdot 5-8 \cdot 2) \\
5 \cdot 7(2 \cdot 9-8 \cdot 5)\end{array}$ & 0.76 \\
\hline
\end{tabular}

TABLE III-Mean (range) body mass index and basal concentrations of testosterone, follicle stimulating hormone, and prolactin in patients with polycystic ovaries treated with pulsatile luteinising hormone releasing hormone

\begin{tabular}{|c|c|c|c|c|c|c|}
\hline & & $\begin{array}{l}\text { No of } \\
\text { patients }\end{array}$ & $\begin{array}{c}\text { Body mass } \\
\text { index }\left(\mathbf{k g} / \mathbf{m}^{i}\right)\end{array}$ & $\begin{array}{l}\text { Testosterone } \\
(\mathrm{nmol} / \mathrm{l})\end{array}$ & $\begin{array}{c}\text { Follicle } \\
\text { stimulating } \\
\text { hormone }(\mathrm{IU} / \mathbf{l})\end{array}$ & $\begin{array}{l}\text { Prolactin } \\
(\mathrm{mlU} / \mathrm{l})\end{array}$ \\
\hline \multirow[b]{2}{*}{ Ovulation } & YYes & 41 & $22 \cdot 6(18 \cdot 6-33 \cdot 8)^{\star}$ & $2 \cdot 0(0 \cdot 5-4 \cdot 0)^{\star \star}$ & $4 \cdot 5(0 \cdot 6-7 \cdot 9)$ & $255(50-643)$ \\
\hline & No & 13 & $25 \cdot 7(20 \cdot 6-34 \cdot 8)^{\star}$ & $2 \cdot 9(1 \cdot 5-5 \cdot 1)^{\star \star}$ & $4 \cdot 8(0 \cdot 7-7 \cdot 0)$ & $233(111-408)$ \\
\hline \multirow{2}{*}{ Conception } & Yes & 27 & $21 \cdot 6(18 \cdot 6-33 \cdot 8)^{\star \star \star}$ & $2 \cdot 1(0 \cdot 8-4 \cdot 0)$ & $4 \cdot 1(0 \cdot 6-5 \cdot 1)$ & $254(50-557)$ \\
\hline & No & 27 & $25 \cdot 0(19 \cdot 0-34 \cdot 8)^{\star \star \star}$ & $2 \cdot 3(0 \cdot 5 \cdot 5 \cdot 1)$ & $4 \cdot 8(0 \cdot 7-7 \cdot 9)$ & $250(61-643)$ \\
\hline \multirow{2}{*}{$\begin{array}{l}\text { Outcome of } \\
\text { pregnancy }\end{array}$} & Early loss & 9 & $21 \cdot 7(18 \cdot 6-29 \cdot 6)$ & $1 \cdot 8(0 \cdot 8-3 \cdot 3)$ & $4 \cdot 4(1 \cdot 8-6 \cdot 6)$ & $351(128-537)$ \\
\hline & Delivery & 18 & $21 \cdot 5(18 \cdot 6-33 \cdot 8)$ & $2 \cdot 2(1 \cdot 0-4 \cdot 0)$ & $4 \cdot 0(0 \cdot 6-7 \cdot 2)$ & $222(50-557)$ \\
\hline
\end{tabular}

${ }^{\star} \mathrm{p}=0.02,{ }^{\star \star} \mathrm{p}=0.01,{ }^{\star \star \star} \mathrm{p}=0.003$. to outcome (early loss or delivery (including the two late abortions))

Table I shows the basal serum luteinising hormone concentrations in each group. These concentrations were significantly lower in women who conceived than those who did not and in those whose pregnancy progressed beyond the first four weeks compared with those who suffered an early pregnancy loss. There was no significant difference between the basal luteinising hormone concentrations of women who did and did not ovulate. Though there was no difference in concentration between those who did not ovulate and those who ovulated but did not conceive (mean 17.0 (range $3 \cdot 5-29 \cdot 7) \mathrm{IU} / \mathrm{l})$, the concentrations were significantly lower in those who ovulated and did conceive $(12.4$ $(1 \cdot 3-29 \cdot 0) \mathrm{IU} / \mathrm{l} ; \mathrm{p}=0 \cdot 048)$. Serum luteinising hormone concentrations were measured in 23 patients during the phase of maximum follicular growth (table II). The concentrations in these patients before treatment were not significantly different from those in the remaining 31 patients. Nineteen of them ovulated, 10 conceived, and four suffered an early pregnancy loss. Those who ovulated had significantly lower luteinising hormone concentrations at the time of maximum follicular growth than those who did not. Those who conceived had significantly lower concentrations during this time than those who did not. No significant difference was found in concentrations during the follicular phase between those who had an early pregnancy loss and those whose pregnancy progressed, but numbers available for study were small.

Table III shows that, while both a high body mass index and a raised serum testosterone concentration were significant adverse prognostic features for induction of ovulation, neither influenced the outcome of pregnancy. Mean basal concentrations of follicle stimulating hormone and prolactin were not significantly different between those who did and did not ovulate, those who conceived and those who did not, and those with early pregnancy loss and those who delivered.

\section{Discussion}

The rate of ovulation ( $54 \%$ of cycles, $76 \%$ of patients), the cumulative rate of conception at six months $(50 \%)$, and the rate of early pregnancy loss $(33 \%)$ in the 54 patients studied were all disappointing when compared with the results of the same treatment in patients with hypogonadotrophic hypogonadism. In women with the polycystic ovary syndrome obesity and hyperandrogenism are adverse factors for induction of ovulation with luteinising hormone releasing hormone,${ }^{4}$ but the present study indicates that raised basal serum luteinising hormone concentrations and, more specifically, raised luteinising hormone concentrations at the time of maximum follicular growth significantly interfere with conception and may be a causal factor in early pregnancy loss. Exposure of the ovaries to high concentrations of luteinising hormone during the phase of follicular growth thus seems to be deleterious to the developing oocyte. ' Because, however, we measured luteinising hormone at the time of maximum follicular growth in only four patients who did not ovulate, the significant difference in concentrations between patients who did and did not ovulate (table II) must be interpreted with caution.

In the normal ovulatory cycle the oocyte is fully mature 36-48 hours before ovulation, and timely maturation is a prerequisite for successful fertilisation and development of the embryo. Up to this time the progress of meiosis is thought to be inhibited by a factor that is itself inhibited by the action of luteinising hormone at mid-cycle, so ensuring ovulation of an egg matured at the appropriate time. ${ }^{89}$ We hypothesise 
that when concentrations of luteinising hormone are high throughout the follicular phase, as in some women with polycystic ovaries, the hormone penetrates the follicle and allows the oocyte to mature prematurely, resulting in ovulation of an oocyte that is physiologically "aged." Such oocytes are unlikely to be fertilised or will tend to produce embryos that implant poorly and therefore abort. Data that support this model were reported in studies of pigs in which premature ovulation (and presumably maturation of oocytes) was induced with human chorionic gonadotrophin $^{10}$ and in studies of rats in which insemination was delayed. ${ }^{11}$ In both studies the interval between maturation of the oocytes and fertilisation was extended and rates of fertilisation and embryo survival were impaired. In women extension of the interval between ovulation and insemination was associated with a striking increase in the rate of miscarriage. ${ }^{12}$ Moreover, Stanger and Yovitch, Howles et al, and Punnonen $e t$ al have reported that high concentrations of luteinising hormone in the few days before oocytes were collected from women for in vitro fertilisation were associated with impaired rates of fertilisation and conception. ${ }^{13-15}$

Our results show that high concentrations of luteinising hormone during the follicular phase, found in many women with the polycystic ovary syndrome, have a deleterious effect on the success of induction of ovulation and conception and may be a causal factor in early pregnancy loss. As recent studies suggest that the polycystic ovary syndrome is common, both in patients attending infertility clinics and in the general population, ${ }^{16} 17$ many patients may perhaps experience early miscarriage because of an endocrine disturbance. A potential treatment for these patients is to induce ovulation with exogenous gonadotrophins after desensitisation of the pituitary with a superactive analogue of luteinising hormone releasing hormone. ${ }^{7}$

1 Armar NA, Adams J, Jacobs HS. Induction of ovulation with gonadotrophin releasing hormone. In: Bonnar J, ed. Recent advances in obstetrics and Emacolog. Vol 15. Edinburgh and London: Churchill Livingstone, gynaecology.

2 McArthur JW, Ingersoll FM, Worcester J. The urinary excretion of interstitial cell and follicle stimulating hormone activity by women with diseases of the reproductive system. $\mathcal{F}$ Clin Endocrinol Metab 1958;18:1202-15.

3 Abdulwahid NA, Adams J, Van der Spuy ZM, Jacobs HS. Gonadotrophin control of follicular development. Clin Endocrinol (Oxf) 1985;23:613-26.

4 Eshel A, Abdulwahid NA, Armar NA, Adams J, Jacobs HS. Pulsatile luteinising hormone releasing hormone therapy in women with polycystic ovary syndrome. Ferril Steril 1988;49:956-60.

5 Adams J, Franks S, Polson DW, et al. Multifollicular ovaries: clinical and endocrine features and response to pulsatile gonadotrophin releasing hormone. Lancet 1985;ii:1375-8.

6 Mason P, Adams J, Morris DV, et al. Induction of ovulation with pulsatile luteinising hormone releasing hormone. $\mathrm{Br}$ Med $\mathrm{f}$ 1984;288:181-5.

7 Jacobs HS, Porter RN, Eshel A, Craft I. Profertility uses of LHRH analogues. In: Vickery BH, Nestor JJ Jr, eds. LHRH and its analogues: contraceptive and therapeutic applications. Part 2. Lancaster: MTP Press, 1987:303-22.

8 Tsafriri A, Pomerantz SH. Oocyte maturation inhibitor. Clin Endocrinol Metab 1986;15:157-70.

9 Dekel N. Hormonal control of ovulation. In: Litwack G, ed. Biochemical actions of hormones. Vol 13. Orlando, Florida: Academic Press, 1986:57-90.

10 Hunter RHF, Cook B, Baker TG. Dissociation of response to injected gonadotrophin between the Graafian follicle and oocyte in pigs. Nature 1976;260:156-8.

11 Austin CR. The egg. In: Austin CR, Short RE, eds. Reproduction in mammals, Part 1. Germ cells and fertilisation. 2nd ed. Cambridge: Cambridge University Press, 1982:58.

12 Guerrero RJ, Rojas OI. Spontaneous abortion and ageing of human ova and spermatozoa. N Engl f Med 1975;293:573-5.

13 Stanger JD, Yovitch JL. Reduced in vitro fertilisation of human oocytes from patients with raised basal luteinising hormone levels during the follicular phase. Br 7 Obstet Gynaecol 1985;92:385-90.

14 Howles CM, MacNamee MC, Edwards RG, Goswamy R, Steptoe PC. Effect of high tonic levels of luteinising hormone on outcome of in vitro fetilisation. Lancet 1986;ii:521-3.

15 Punnonen R, Heinonen PK, Ashorn R, Kujansuu E, Vilja P, Tuohimaa P. Spontaneous luteinizing hormone surge and cleavage of in vitro fertilized embryos. Fertil Steril 1988;49:479-82.

16 Adams J, Polson DW, Franks S. Prevalence of polycystic ovaries in women with anovulation and idiopathic hirsutism. Br Med f 1986;293:355-9.

17 Polson DW, Adams J, Wadsworth J, Franks S. Polycystic ovaries - a commo finding in normal women. Lancet 1988; i:870-2.

(Accepted 9 fune 1988)

\section{Absence of end diastolic frequencies in umbilical artery: a sign of fetal hypoxia and acidosis}

\author{
K H Nicolaides, C M Bilardo, P W Soothill, \\ S Campbell
}

Harris Birthright Research Centre for Fetal Medicine, King's College School of Medicine and Dentistry, London SE5 8RX

K H Nicolaides, MRCOG, senior lecturer

C M Bilardo, MD, research

fellow

P W Soothill, MB, research

fellow

S Campbell, FRCOG, professor

Correspondence to: $\mathrm{Dr}$ Nicolaides.
One of the main challenges of antenatal management is distinguishing between normal small fetuses and growth retarded fetuses, which are at increased risk of intrauterine death or asphyxia at birth. Cordocentesis and analysis of fetal blood gases have shown that some fetuses that are small for gestational age are chronically hypoxic and acidotic. ${ }^{12}$ Cordocentesis, however, is an invasive procedure and not widely available. In hypoxic fetuses the blood velocity in the aorta is decreased. ${ }^{3}$ Doppler measurement of blood velocity is non-invasive but requires expensive pulsed Doppler equipment and an experienced operator. The presence or absence of end diastolic frequencies in the umbilical artery can be ascertained with continuous wave Doppler equipment, which is much cheaper and requires less training of the operator. We examined the relation of the oxygen tension and $\mathrm{pH}$ in fetal blood with the absence of end diastolic frequencies in flow velocity waveforms of the umbilical artery.

\section{Methods and results}

We studied the fetuses of 59 healthy pregnant women who had been referred from other units for investigation of fetal growth retardation. The fetuses were of 21-36 weeks' gestation and had an abdominal circumference below the fifth centile of our normal range. Blood flow velocity waveforms for the umbilical artery were obtained with continuous wave Doppler ultrasound and analysed by a spectrum analyser (Doptek Spectrascan analyser 9000, Doptek, Chichester). A $100 \mathrm{~Hz}$ filter was used to eliminate the low frequencies obtained from movements of the arterial wall. With the mother semirecumbent and the fetus apnoeic, the Doppler probe was moved over the uterus until the umbilical cord waveform was identified
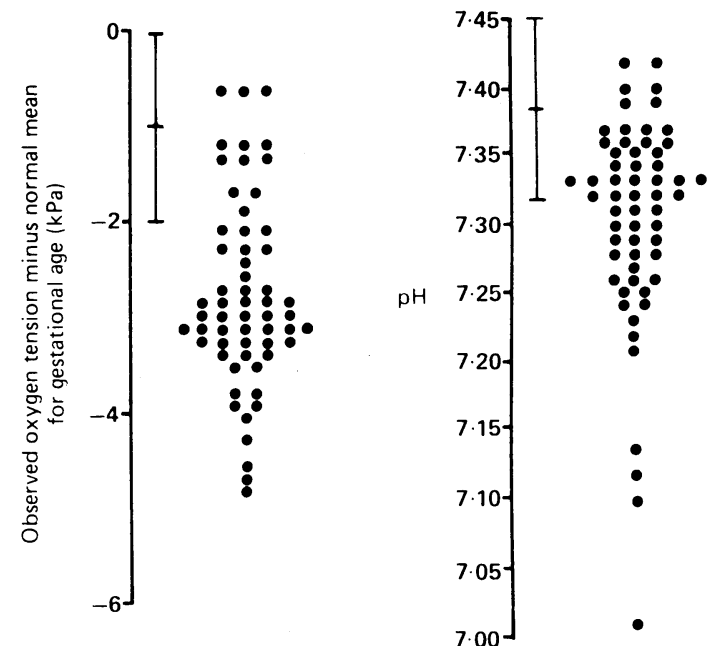

Severity of hypoxia and acidosis in 59 fetuses that were small for gestational age and in which end diastolic frequencies of blood flow in the umbilical artery were absent on continuous wave Doppler ultrasound scanning. Vertical bars show normal range (2SD either side of mean) 